\title{
The Vegetation and floristics of The NKhuhlu Exclosures, Kruger National Park
}

\author{
FRANCES SIEBERT \\ School of Environmental Sciences and Development \\ North-West University \\ South Africa \\ HOLGER C. ECKHARDT \\ Scientific Services \\ South African National Parks \\ South Africa
}

Correspondence to: Frances Siebert

e-mail: frances.siebert@nwu.ac.za

Postal Address: School of Environmental Sciences and Development, North-West University, Private Bag X6001, Potchefstroom 2520

\begin{abstract}
The need to conduct research on the impact of elephant on the environment prompted the construction of exclosures along two of the most important rivers in the Kruger National Park. Scientific research on these exclosures along the Sabie and Letaba rivers addresses how patterns of spatial and temporal heterogeneity of the riparian zone are affected by fire, flood and herbivory. To further assist this research programme, a vegetation survey was conducted at the Nkhuhlu exclosure site along the Sabie River to classify and map the vegetation of the area. This will provide baseline data to assess future changes in vegetation and floristic patterns due to small-scale environmental factors created by the presence/absence of herbivory and fire. Phytosociological data were analysed to identify plant communities and subsequent mapping units. Five plant communities, ten sub-communities and four variants were recognised and described in relation to prevailing soil forms. Differences in species richness, diversity and community structure of the plant communities are clearly articulated.
\end{abstract}

Keywords: Sabie River, biodiversity, savanna, riparian vegetation, vegetation mapping

Management of the Kruger National Park (KNP) is, now more than ever before, facing the challenge of dealing with an increasing elephant population in a way that will satisfy not only a series of stakeholders and interested parties but also a large proportion of the public, both nationally and internationally. The moratorium on elephant culling was introduced in 1994 and ever since elephant numbers steadily increased by approximately $6 \%$ per annum. Certain preferred areas within their home ranges started to show signs of adverse impacts related to increasing elephant densities, usually in the form of tree debarking and pollarding. Such impacts were also recorded several decades ago based on research and monitoring work conducted by Coetzee et al (1979), Engelbrecht (1979), Viljoen (1988), Trollope et al (1998), and Eckhardt et al (2000). The idea of erecting exclosures was therefore directly related to the elephant management problem that was present since 1979, but only became visible recently. The exclosures were built to develop an understanding of spatial and temporal heterogeneity patterns around the riparian zone, and how these are affected by fire and herbivory. The application for funding, of which the largest amount was contributed by the National Science Foundation of the United States of America, was strengthened by the flood in 2000, which created unexpected opportunities to investigate ecological processes associated with the postflood legacy. While the funding agreement stipulated that the riparian and transitional zones should receive the necessary attention, the area of interest was extended to include the whole catenal sequence from the rivers to the crests.

The Nkhuhlu exclosures in the south of the KNP form part of a set of exclosures that were built in 2002 to determine the effect of two important ecosystem modifiers, namely elephant and fire, by excluding them from the ecosystem, while at the same time trying to understand how river ecosystems recover after large infrequent disturbances. The exclosures consist of six treatments, namely 1) a fully fenced area (70 ha) excluding all herbivores, divided into a burn and no-burn block; 2) a partially fenced area (44 ha) excluding only elephants and giraffes, also divided into a burn and no-burn block; 3) an unfenced area (25 ha) protected from fire only; and 4) a buffer area to the south and east of the exclosures subjected to fire and herbivory. The main objective is to understand the effect of the different treatments on vegetation patterns, associated biota, soil moisture and nutrient cycling. The topography with its specific soil and vegetation types can be divided into recognisable units, representing crests, mid- and footslopes, and valley-bottoms. These larger units, also referred to as patches, are key elements of various research projects, including a detailed soil inventory (Paterson \& Steenekamp 2003). Some of the completed and current projects investigated the dynamics of large woody debris piles (Pettit et al 2006; Pettit \& Naiman 2006; Pettit \& Naiman 2007a; Pettit \& Naiman 2007b), biogeochemistry and plant productivity in riparian ecotones (Jacobs 2003), effects of browsing and season on defence and growth of woody plants (Scogings 2005), and regeneration ecology of selected woody species in the absence and presence of herbivory and fire (Wilson 2003). Most of the research projects conducted so far had to rely on broadly-defined vegetation units to provide spatial context since no 'formal' vegetation classification existed for the Nkhuhlu exclosures. The need for this type of classification prompted this project, thereby producing a hierarchical classification comprising zonal and azonal plant communities. This detailed vegetation classification, interpreted in terms of environmental factors, will hopefully contribute to improved interpretations and better understanding of patch dynamics at various spatial scales as driven by the absence and presence of herbivory and fire.

\section{STUDY AREA}

The study area is located approximately $18 \mathrm{~km}$ downstream of Skukuza along the Sabie River, directly opposite Nkhuhlu picnic site. It comprises an area of 139 ha, divided into smaller 


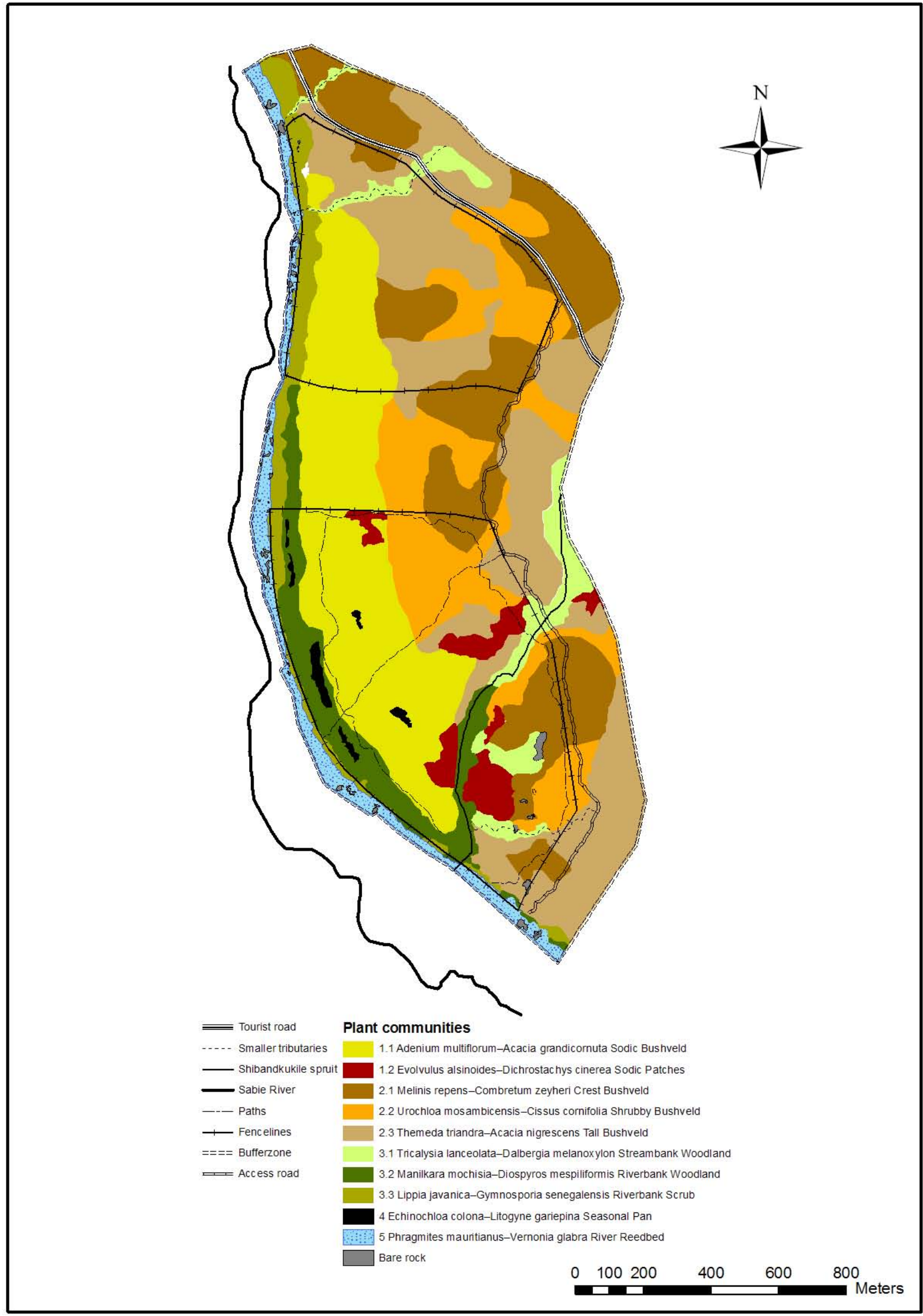

FIGURE 1

Vegetation map of the Nkhuhlu exclosure site 
units, each of which is subjected to a different treatment as discussed above. The mean annual rainfall is approximately 561 $\mathrm{mm}$ as measured at Skukuza, while the mean daily temperature is $21.9{ }^{\circ} \mathrm{C}$, ranging from $5.6^{\circ} \mathrm{C}$ in winter to a high of $32.6{ }^{\circ} \mathrm{C}$ in summer (Weather Bureau 1986).

Soils vary between shallow sandy soil directly overlying weathering rock on the crests and deep sand to sandy loam along the Sabie River. The footslopes consist primarily of sodic patches that are characterised by sodium-rich duplex soils. Due to the high nutrient status animals favour these patches, which often results in overgrazing of the herbaceous layer.

The vegetation of the Nkhuhlu exclosure site falls under the 'Thickets of the Sabie and Crocodile Rivers' landscape described by Gertenbach (1983). This vegetation type is also referred to as the Acacia nigrescens-Combretum apiculatum association (Gertenbach 1983), with Acacia nigrescens, Combretum apiculatum, Grewia bicolor, G. flavescens, Dichrostachys cinerea, Euclea divinorum, Terminalia prunioides, Spirostachys africana and Acacia grandicornuta as differentiating woody species of which all of the above are conspicuously present at the Nkhuhlu exclosure site. Gertenbach (1983) identified two variations within this type, both strongly represented at the Nkhuhlu exclosure site. They include the Acacia grandicornuta-dominated bottomlands and the Combretum apiculatum-dominated uplands. Coetzee (1983) identified the Sabie River valley as Tropical Arid Granitic Lowveld, which includes five different vegetation types (landscape units), all of which are well represented within the Nkhuhlu exclosure site. Bredenkamp and Van Rooyen (1991) mapped and described the riparian vegetation of the Sabie River. Both major plant communities identified and described by Bredenkamp and Van Rooyen (1991) are represented along the riparian zone within the Nkhuhlu exclosure site, although not all smaller variations have been observed, especially not those overlying rhyolite. On a national scale, the Nkhuhlu exclosure site forms part of the Granite Lowveld vegetation type (SVI 3) within the Lowveld Bioregion of the revised vegetation map of South Africa, Lesotho and Swaziland (Mucina et al. 2005).

\section{METHODS}

\section{Classification and mapping}

Relevés containing detailed floristic and habitat data were obtained from 74 stratified random sample plots identified from 1 : 5000 aerial photographs. Surveying was done within the full, partial and unfenced areas, the $400 \mathrm{~m}$ buffer zone and the 'sacrificial zone' (i.e. the narrow strip between the Sabie River macro-channel and the riverbank, in most instances the reed bed). Within each sample plot (20 m x $20 \mathrm{~m}$ in size), all plant species were recorded and a cover-abundance value was assigned to each species according to the Braun-Blanquet scale (Mueller-Dombois \& Ellenberg 1974). Plant species names conform to those of Germishuizen and Meyer (2003). Vegetation structure for each plot was described using field observations and Edwards's broad-scale structural classification (1983). Other data recorded for each sample plot include tree height, slope and rock cover.

Plot data was entered into a vegetation database in the TURBOVEG program (Hennekens 1996b). A first approximation of the vegetation classification was obtained by the application of the Two-Way Indicator Species Analysis (TWINSPAN) (Hill 1979) in the MEGATAB computer program (Hennekens 1996a). Braun-Blanquet procedures were used to further refine the resultant classification. This final product is presented in a phytosociological table (Table 1). Results from the classification and subsequent refinement were used to construct a $1: 5000$ vegetation map for the Nkhuhlu exclosure site (Figure 1).
Mapping was done up to the sub-community level in ArcMap ${ }^{\mathrm{TM}}$ of the Esri ArcGIS 9.1® computer package. To improve the understanding of the map in terms of the topography, the distribution of the plant communities is presented in a profile drawing (Figure 2) which was constructed using Corel Draw Suite $9^{\circ}$.

\section{Floristic analysis}

Floristic data was analysed to strengthen floristic comparison across mapping units and is therefore presented on subcommunity level. Alpha diversity (species richness) for each sub-community (mapping unit) was calculated as the mean number of plant species in all relevés that constitute the subcommunity (mapping unit). Shannon-Wiener diversity indices were used to combine species richness and relative abundance among species (Barbour et al 1987) for comparison across mapping units. The Braun-Blanquet cover abundance scale was converted to percentage cover, and the mean cover per species within the plant community was taken as its abundance value by using the midpoint value conversion (Mueller-Dombois \& Ellenberg 1974). Mean vegetation cover percentage (MCP) was determined for each species in each community. MCP is the sum of a species' percentage cover in all the relevés of a community, divided by the total number of relevés for that community (species cover was determined using the following conversion from the Braun-Blanquet scale: $\mathrm{r}=0.5 \%$; $+=1 \%$; $13 \% ; 2 \mathrm{a}=8 \% ; 2 \mathrm{~b}=18 \% ; 3=37 \%$ ). Richness per life/growth form was also calculated per community and grouped under one of the following in accordance with Germishuizen and Meyer (2003): trees, shrubs, climbers, succulents, forbs, graminoids and annuals.

\section{RESULTS}

\section{Classification and mapping}

A hierarchical classification of the Nkhuhlu data set before refinement revealed five main plant communities, which include 10 sub-communities after refinements. They include the following:

1. Sporobolus nitens-Euclea divinorum Dry Sodic Savanna

1.1 Adenium multiflorum-Acacia grandicornuta Sodic Bushveld

1.2 Evolvulus alsinoides-Dichrostachys cinerea Sodic Patches

2. Enneapogon scoparius-Combretum apiculatum Dry Mixed Savanna

2.1 Melinis repens-Combretum zeyheri Crest Bushveld

2.1.1 Xerophyta retinervis variant

2.1.2 Acacia exuvialis variant

2.2 Urochloa mosambicensis-Cissus cornifolia Shrubby Bushveld

2.3 Themeda triandra-Acacia nigrescens Tall Bushveld

2.3.1 Ptaeroxylon obliquum variant

2.3.2 Themeda triandra typical variant

3. Jasminum fluminense-Spirostachys africana Riverine Forest 3.1 Tricalysia lanceolata-Dalbergia melanoxylon Streambank Woodland 3.2 Manilkara mochisia-Diospyros mespiliformis Riverbank Woodland 3.3 Lippia javanica-Gymnosporia senegalensis Riverbank Scrub

4. Echinochloa colona-Litogyne gariepina Seasonal Pan

5. Phragmites mauritianus-Vernonia glabra River Reedbed

5.1 Cynodon dactylon-Breonadia salicina Rocky Reedbed

5.2 Dactyloctenium geminatum-Ficus capreifolia Sandy Reedbed

These plant communities are distributed throughout the Nkhuhlu study area of which some extend over the borders and are shared by different exclosure types (Figure 1).

Vegetation mapping was done up to the sub-community level where the distribution of units is neither too locally scaled nor overlapping. The resultant map (Figure 1) shows that some communities have a limited distribution range, such as the Evolvulus alsinoides-Dichrostachys cinerea Sodic Patches (1.2) and the Echinochloa colona-Litogyne gariepina Seasonal Pans (4). The limited distribution of these communities can be attributed to 


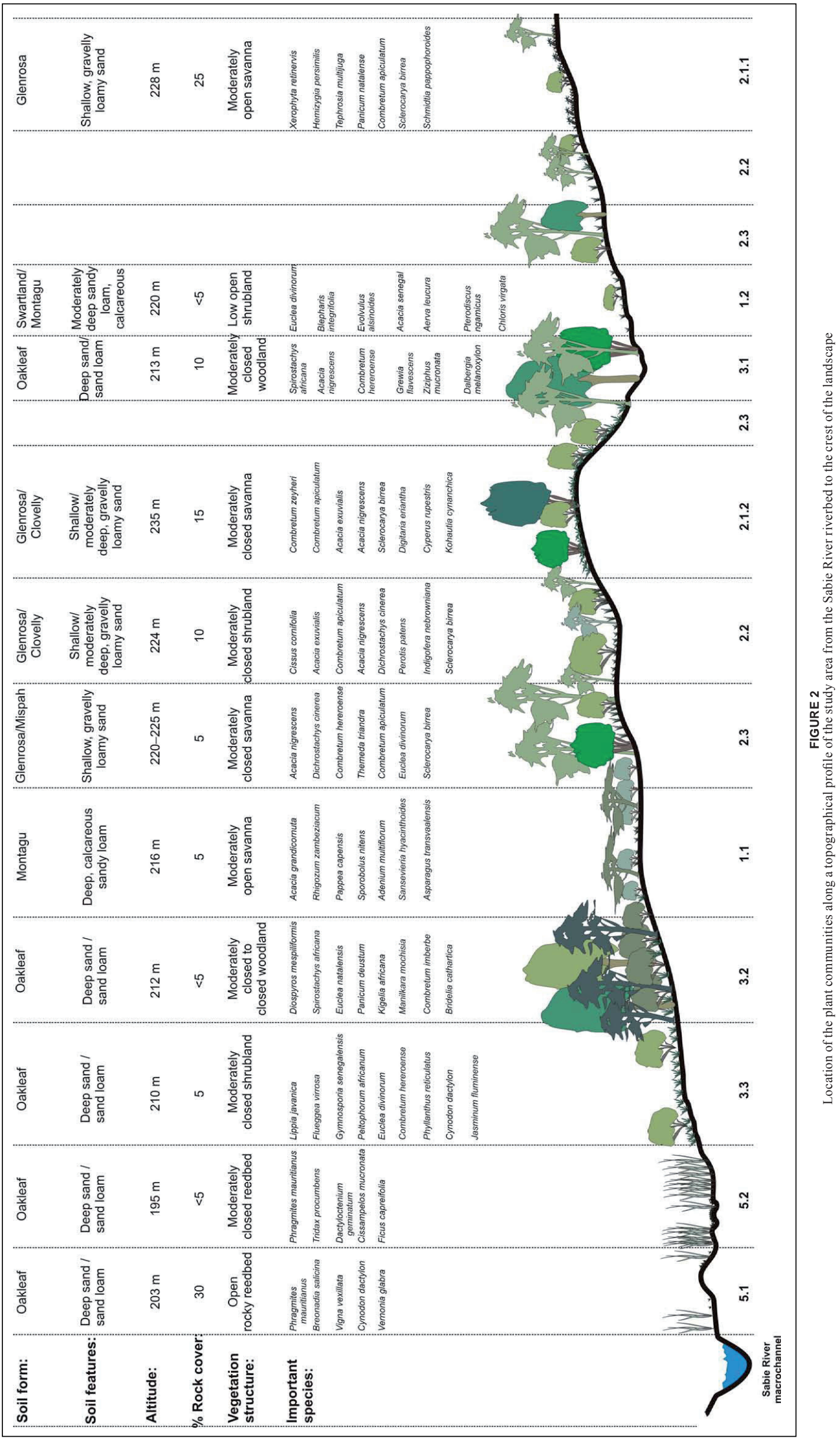




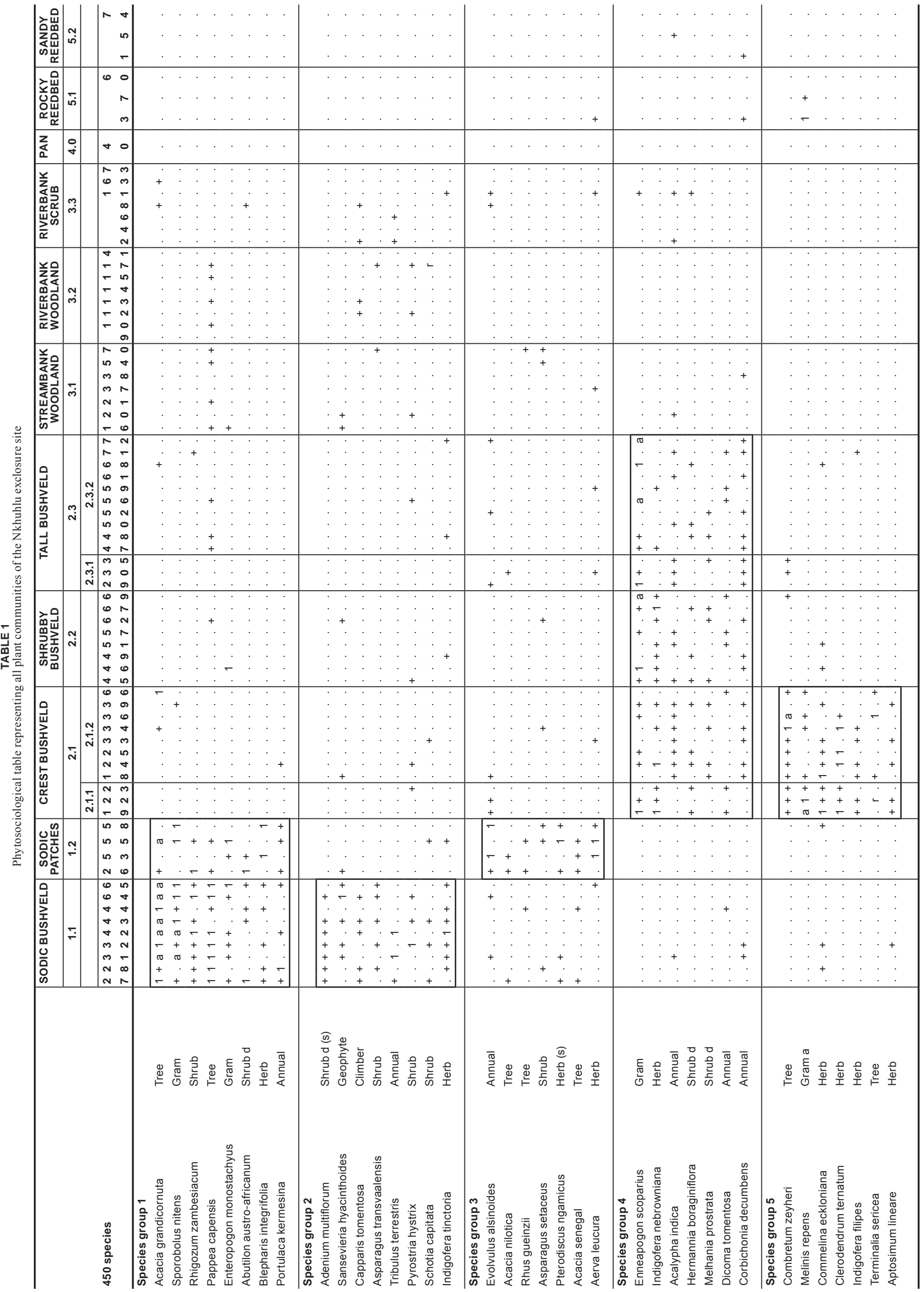




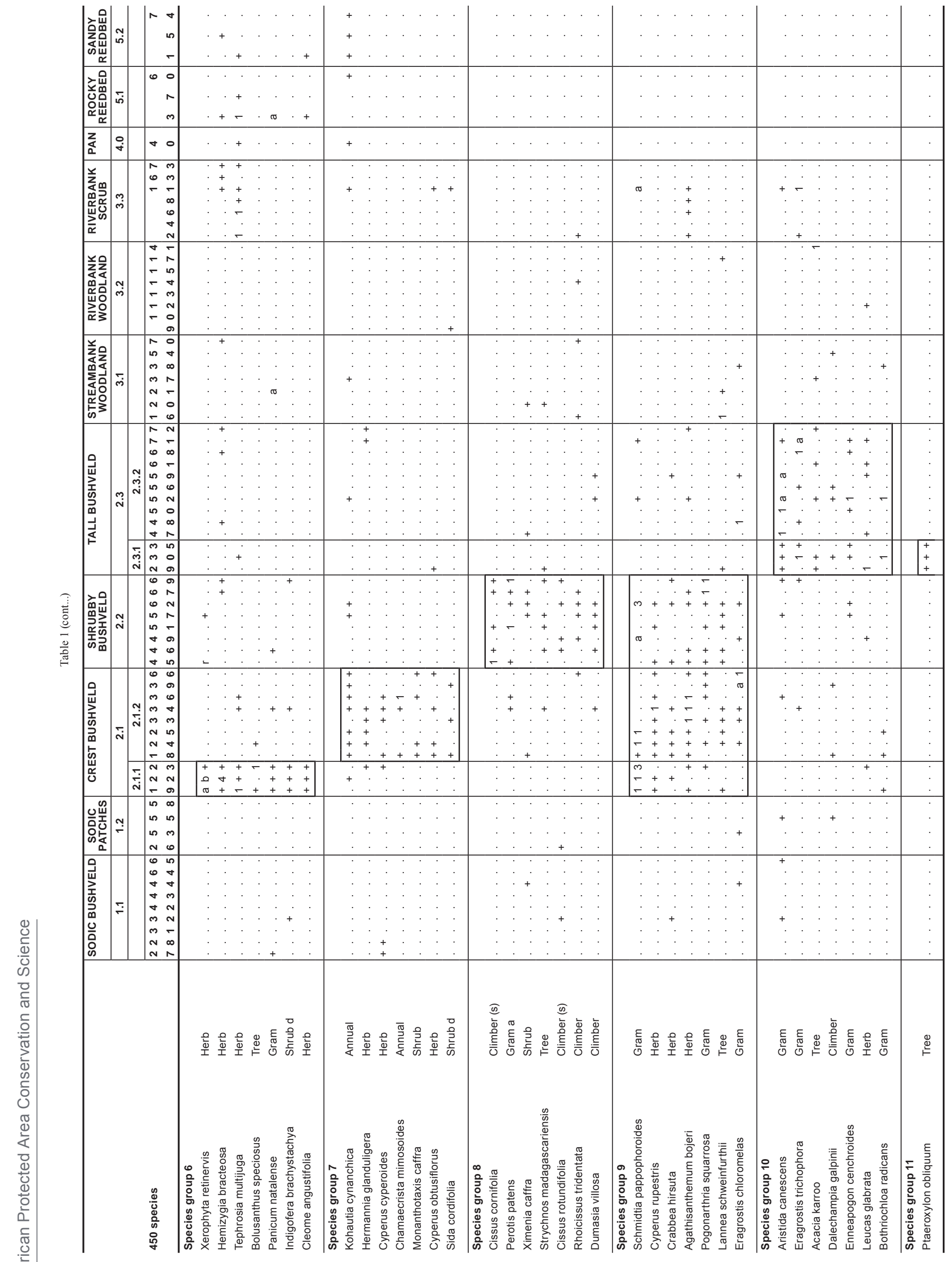




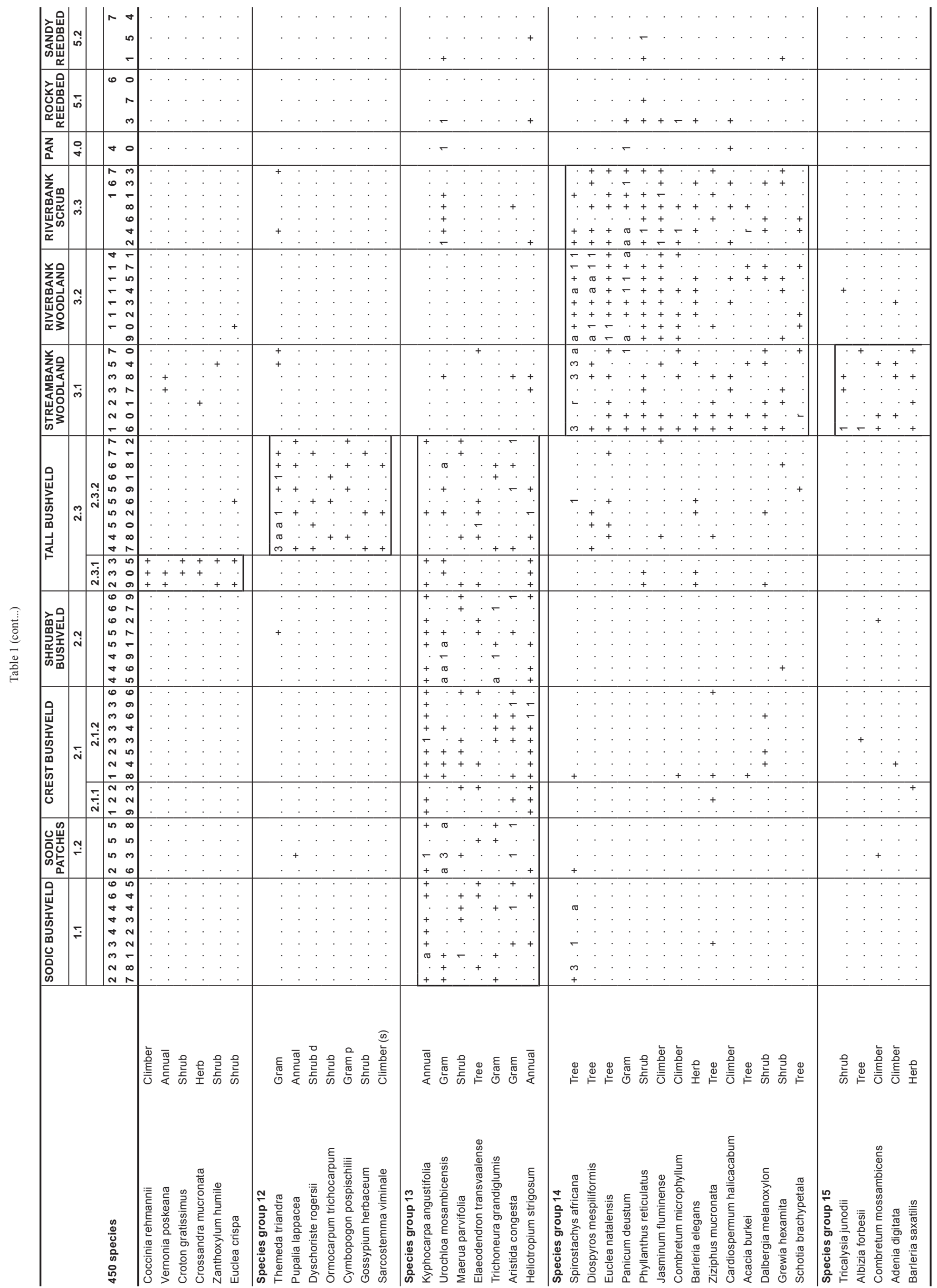




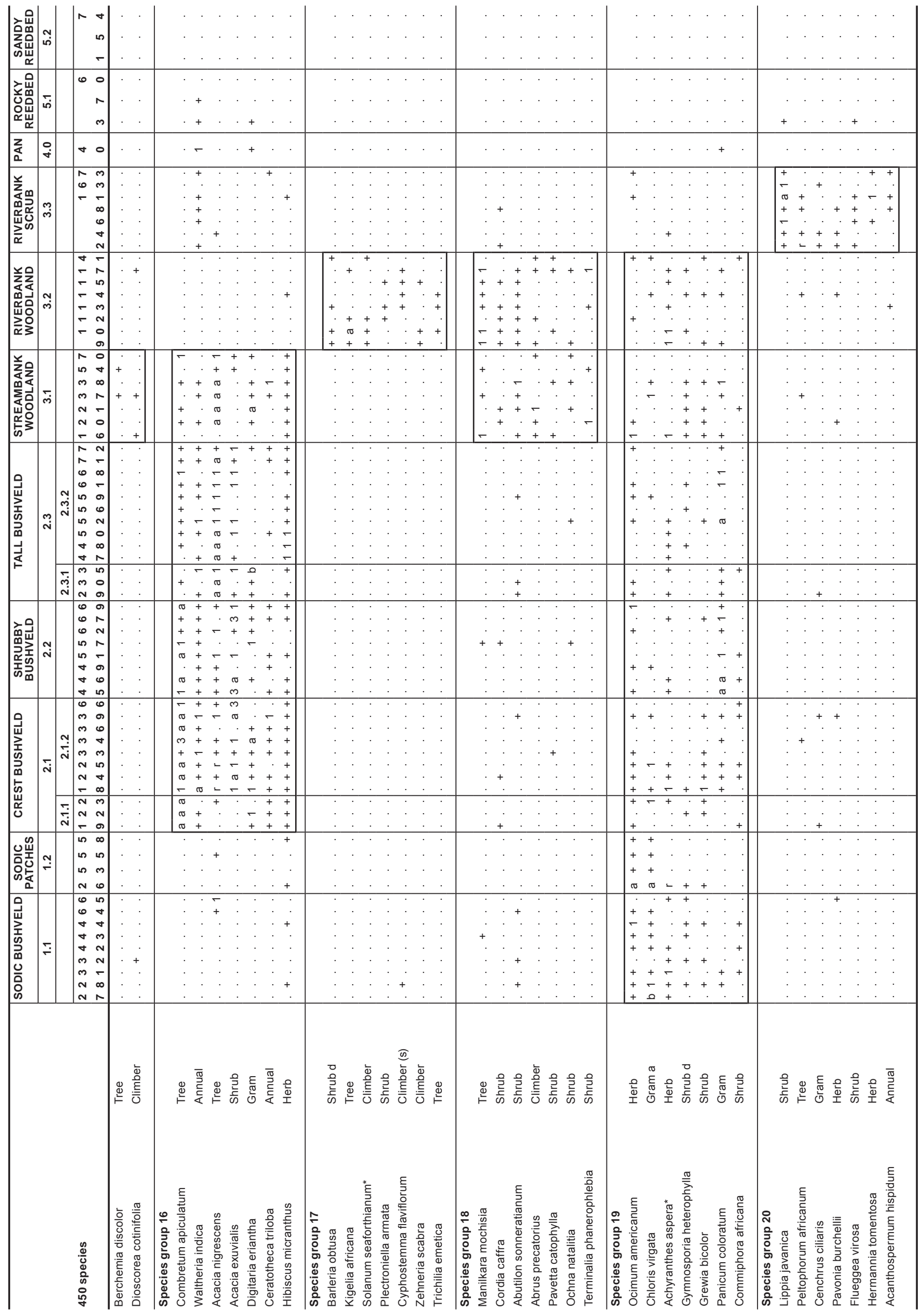




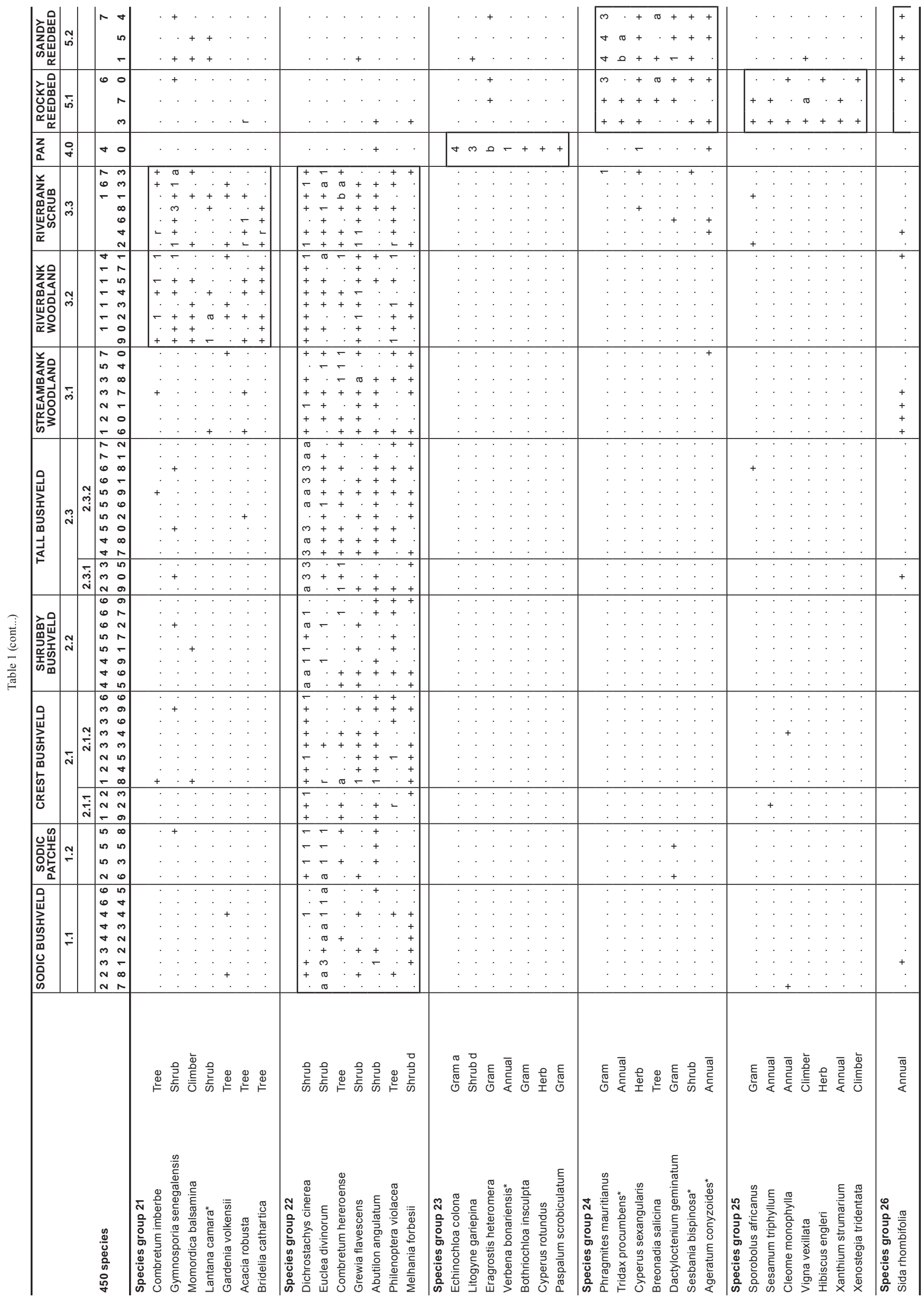




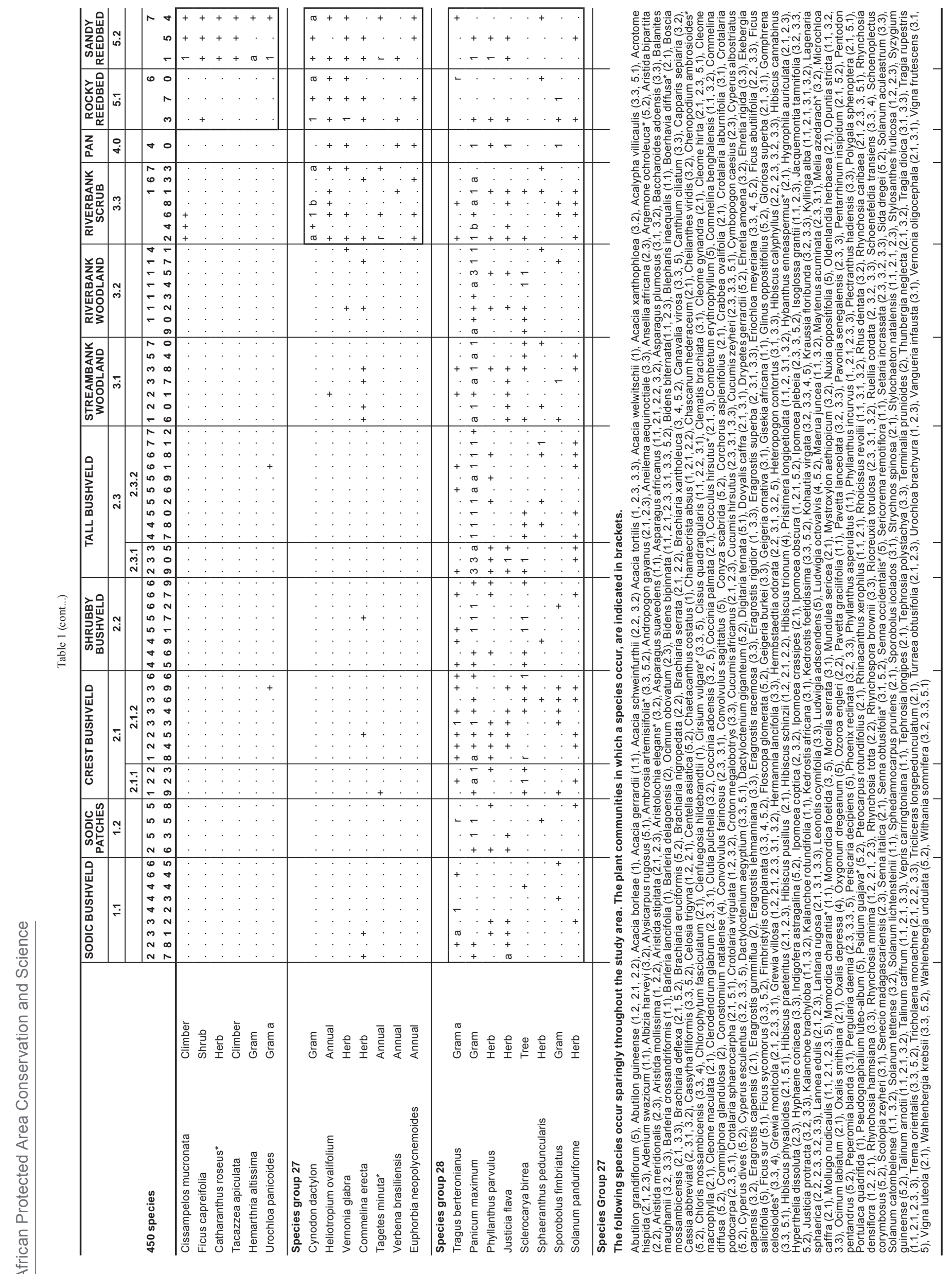


small-scale patchiness caused by small-scale environmental factors. Most of the plant communities are easily recognisable in the field. There is a gradual, but well-defined change in plant community distribution from the Sabie River macro-channel to the crest of the landscape (Figure 2), namely from the Phragmites mauritianus-Vernonia glabra River Reedbed (5) via the Lippia javanica-Gymnosporia senegalensis Riverbank Scrub (3.3) or Manilkara mochisia-Diospyros mespiliformis Riverbank Woodland (3.2) to the savanna landscape of the Nkhuhlu exclosure site (Figure 2). It is, however, within the savanna zone where sub-communities are not distinctly delineated due to a conglomerate of small-scale environmental variances in soil and topography. It is specifically community 2, the Enneapogon scoparius-Combretum apiculatum Dry Mixed Savanna, where so many conspicuous species are shared among the three subcommunities that vegetation units are not easily distinguishable in the field (Table 1). While all plant community boundaries represent ecotones and are therefore arbitrary, they may be allocated to one or the other unit. Structural variation and the abundance of typical savanna species delineate these sub-units rather than diagnostic species (Table 2).

\section{Floristic analysis}

At community level, species richness is of the highest in the Jasminum fluminense-Spirostachys africana Riverine Forest (community 3) with a total of 262 plant species, and in the Enneapogon scoparius-Combretumapiculatum Dry Mixed Savanna (community 2) with a total of 260 plant species (Table 3). The highest species richness on sub-community level was recorded for the Melinis repens-Combretum zeyheri Crest Bushveld (community 2.1) (Figure 3b). The Shannon-Wiener diversity index (which combines both richness and equitability, i.e. relative abundance among species) showed significant variation across communities and sub-communities (Figure 3, Table 3). Not only does the Jasminum fluminense-Spirostachys africana Riverine Forest (community 3) host the highest diversity (Table 3), it also hosts the sub-community with the highest diversity values, namely the Lippia javanica-Gymnosporia senegalensis Riverbank Scrub (community 3.3) (Figure 3a).
Floristically, the study area is dominated by taxa from the Poaceae, Fabaceae, Asteraceae, Malvaceae and Acanthaceae (Table 4). The dominant growth forms in the study area are forbs, graminoids, trees and shrubs. A high number of climber species were recorded in the study area (58 species), of which five are succulent (Table 5).

\section{DISCUSSION}

\section{Description of plant communities}

The Nkhuhlu study area lies in the geological and climatically uniform Landscape 4 as described by Gertenbach (1983), namely the 'Thickets of the Sabie and Crocodile Rivers'. Hence no major climatic variation plays a role in local differentiation of plant communities. However, all sub-communities are not clearly distinctive in the field but rather form a mosaic pattern created by interchange (sharp variation) in the dominance of plant species. Although there is large-scale homogeneity, smallscale heterogeneity of environmental factors might contribute to this complex transition pattern of habitats and associated vegetation. Descriptions of the plant communities are therefore important to explain the delineation of each of the mapping units.

\section{Sporobolus nitens-Euclea divinorum Dry Sodic Savanna}

The Sporobolus nitens-Euclea divinorum Dry Sodic Savanna belongs to the Chlorico virgatae-Justiceion flavae alliance on deflocculated soil (Coetzee 1983) and more specifically to the granite variant in the sparsely shrubby, moderately brushy bushveld and treeveld with Cyathula crispa (= C. lanceolata) (community 1.1.1 in Coetzee (1983)). It is furthermore strongly related to the Spirostachys africana-Acacia grandicornuta savanna (community 17 in Bredenkamp and Van Rooyen (1991)) on granite and sandstone bottomlands that produce brackish soils.

Covering approximately $23 \%$ of the total sampling area (including the buffer zone), this sweetveld community stretches across exclosure fence lines, showing a marked difference

TABLE 2

Comparison of the vegetation structure, selected environmental factors and character species abundance for the three sub-communities of the Dry Mixed Savanna of the Nkhuhlu exclosure site

\begin{tabular}{|c|c|c|c|c|}
\hline \multirow[b]{2}{*}{ Habitat features } & & \multicolumn{3}{|c|}{ PLANT COMMUNITIES } \\
\hline & & 2.1 & 2.2 & 2.3 \\
\hline Altitude $(\mathrm{m})$ & & 232 & 224 & 225 \\
\hline Habitat type & & Crests & Crests \& Midslopes & Midslopes \& Bottomlands \\
\hline$\%$ Rock cover & & $15-20$ & 10 & 5 \\
\hline Slope $\left({ }^{\circ}\right)$ & & 5 & 3 & 2 \\
\hline Species $/ 400 m^{2}$ & & 56 & 36 & 37 \\
\hline Tree height (m) & & 6 & 6 & 9 \\
\hline Tree cover $(\%)$ & & 18 & 9 & 17 \\
\hline Shrub cover (\%) & & 25 & 37 & 36 \\
\hline Annual species cover (\%) & & 13 & 6 & 6 \\
\hline Forb species & & 54 & 19 & 34 \\
\hline Soil (dominant form in bold) & & Glenrosa/Clovelly & Glenrosa/Clovelly/Mispah & Glenrosa/Mispah/Oakleaf \\
\hline Diagnostic species: & & Combretum zeyheri & Cissus cornifolia & Acacia karroo \\
\hline \multicolumn{5}{|l|}{ Values for selected dominants* } \\
\hline & Combretum apiculatum & 31 & 17 & 11 \\
\hline & Acacia nigrescens & 7 & 8 & 31 \\
\hline & Acacia exuvialis & 18 & 18 & 15 \\
\hline & Dichrostachys cinerea & 14 & 16 & 45 \\
\hline & Euclea divinorum & 1 & 4 & 11 \\
\hline & Combretum hereroense & 7 & 4 & 12 \\
\hline
\end{tabular}




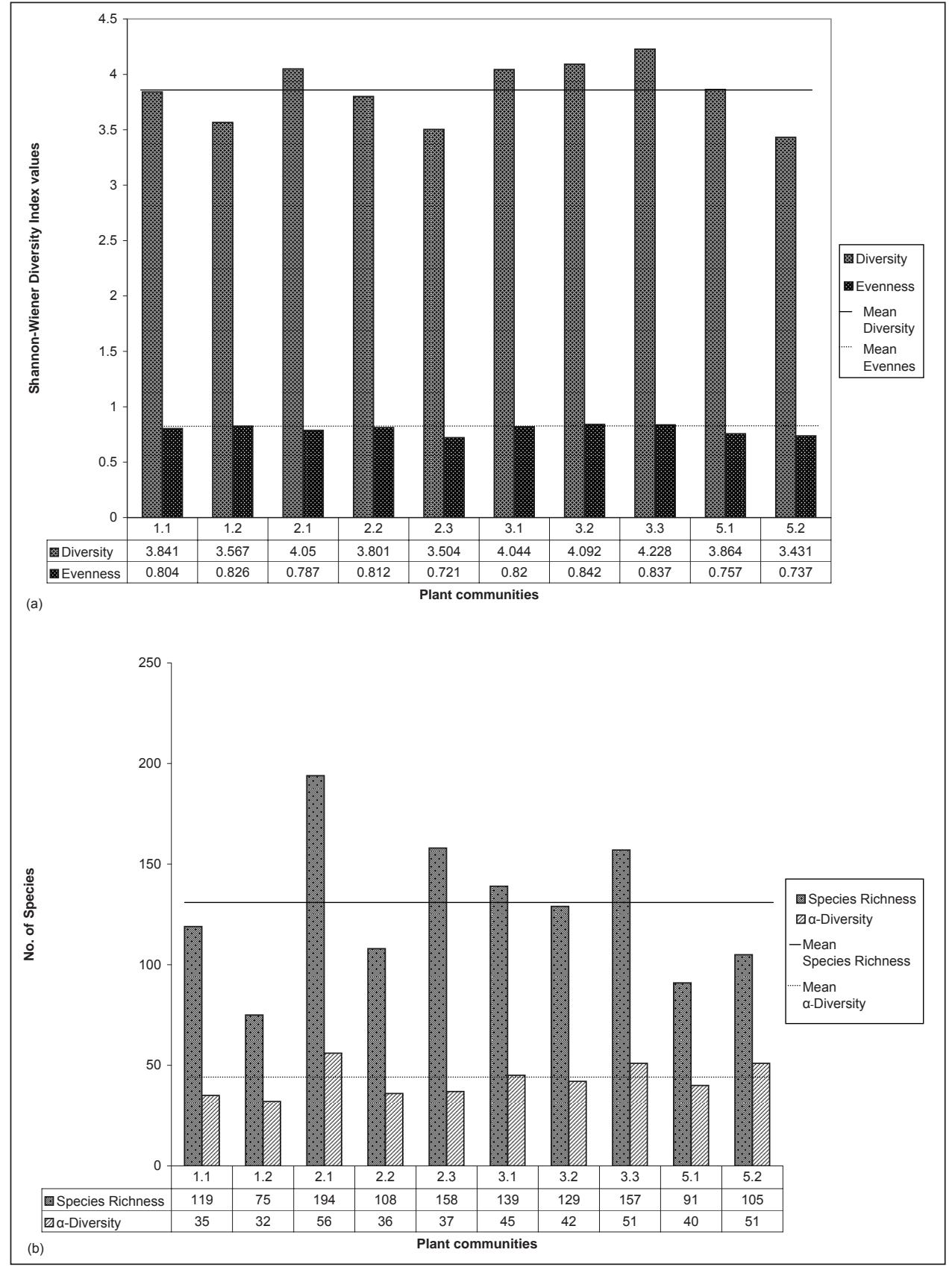

FIGURE 3

Analysis of species diversity, evenness and richness of all plant sub-communities identified for the Nkhuhlu exclosure site: (a) Shannon-Wiener indices of diversity and evenness, and (b) $\alpha$-Diversity (mean no. of species per plot) and species richness (mean no. of species per sub-community)

between the three exclosure types in terms of trampling and overgrazing. It shows a clear decrease in herbaceous cover from the full exclosure to the open area. The largest part of this community is associated with deep, greyish-brown sandy loam topsoil on calcareous yellow-brown sandy clay loam subsoil (Mu, (Montagu soil form)) (Paterson \& Steenekamp 2003). Patches of this community also occur on opposite sides of the Xiphandlukile Stream on Swartland (Sw) and Montagu soil forms (Figure 4).

The vegetation of this community varies from open to moderately open treeveld and is floristically characterised by species group 1 (Table 1). It is dominated by woody species (i.e. trees and shrubs) such as Acacia grandicornuta, Pappea capensis, Rhigozum zambeziacum (species group 1, Table 1), Spirostachys africana (species group 14) and Euclea divinorum (species group 22). The succulent shrub Adenium multiflorum (species group 1) is diagnostic for this community. Important grasses include Enteropogon monostachyus, Sporobolus nitens (species group 1) and Chloris virgata (species group 19), whereas Abutilon austro-africanum, Portulaca kermesina (species group 1), and Ocimum americanum (species group 19) comprise the diagnostic and dominant forbs.

This community is floristically the second weakest with a total of 138 plant species recorded. Diversity, including evenness values, is of the lowest in the study area (Table 3), suggesting that this community is rather uniform and lacks variation. Taxa of the Acanthaceae, Fabaceae and Poaceae dominate the study area floristically (Table 4). The highest number of succulent species was recorded in this community (Table 5).

Two sub-communities were identified in the Sporobolus nitensEuclea divinorum Dry Sodic Savanna and are subsequently discussed: 


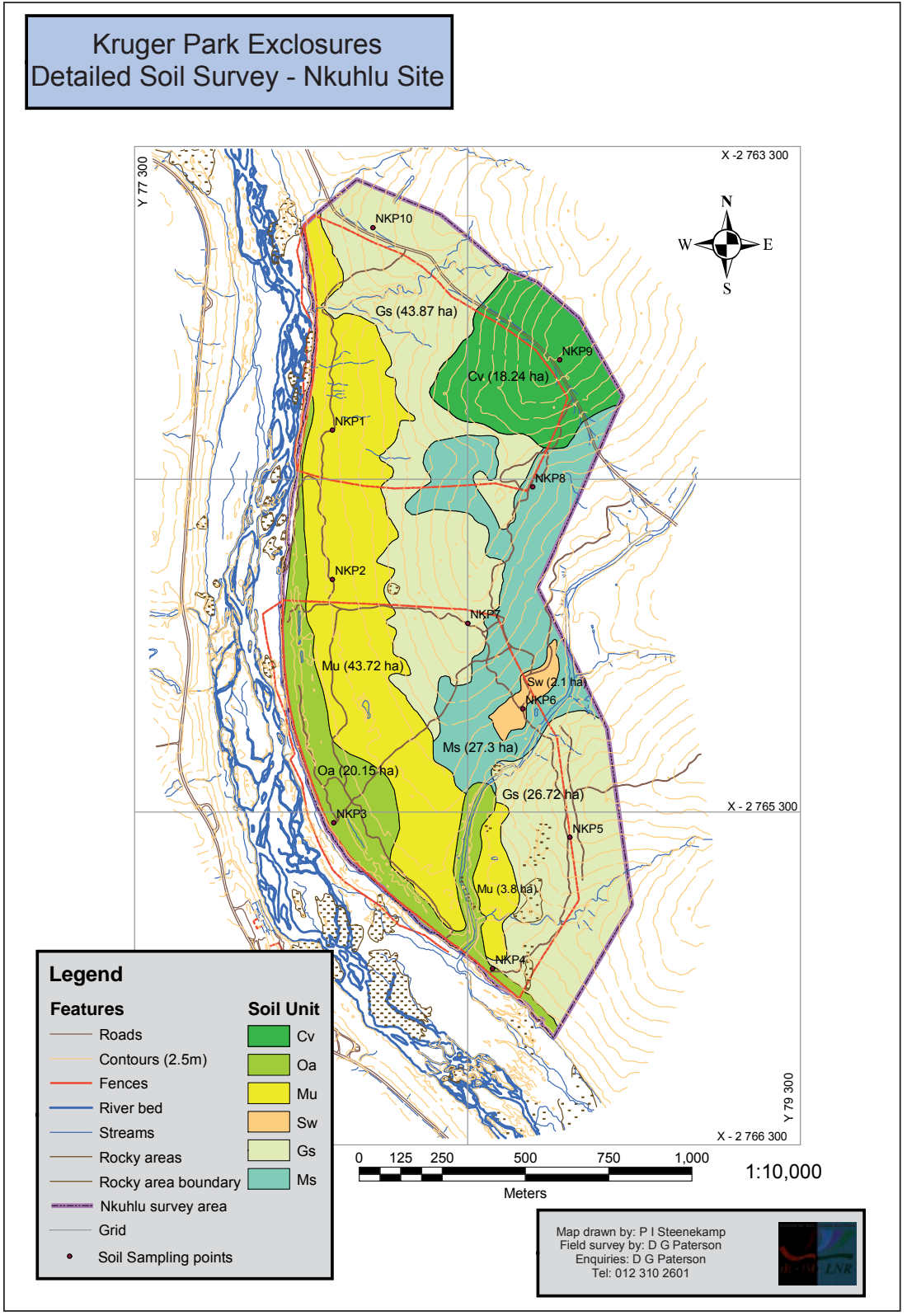

FIGURE 4

Soil map of the Nkhuhlu exclosure site (courtesy of ARC-Institute for Soil, Climate and Water 2003)

1.1 Adenium multiflorum-Acacia grandicornuta Sodic Bushveld

This sub-community is the most representative sub-community of the Sporobolus nitens-Euclea divinorum Dry Sodic Savanna. It covers the bottomlands of the Sabie River on brackish soils of the Montagu soil form (Figure 4), stretching over all three exclosure types, although it is most conspicuously present in the full exclosure (Figure 1). It is generally a moderately open savanna dominated by the tree Acacia grandicornuta, although there is a denser variation within this sub-community in which Pappea capensis forms the dominant tree accompanied by dense stands of Acacia grandicornuta and Euclea divinorum. This variation was identified through observations and could not be supported by the classification results. The impact of heavy grazing and trampling is most distinctive within this community where there is a marked difference in vegetation structure and density between the full exclosure and the areas that permit utilisation. The partial exclosure and the open area are trampled due to heavy grazing and some of the woody plants are severely damaged. The change in floristic composition, however, is not noticeable.
This sub-community is characterised by species group 2 (Table 1) and includes species such as Schotia capitata in the woody layer, succulent shrubs such as Adenium multiflorum and Sansevieria hyacinthoides, and Asparagus transvaalensis, Indigofera tinctoria and Tribulus terrestris in the forb layer. Other conspicuous trees are Rhigozum zambeziacum, Pappea capensis (species group 1), Pyrostria hystrix (species group 2), Maerua parvifolia (species group 13), Euclea divinorum (species group 22) and the woody climber Capparis tomentosa (species group 2). Prominent forbs are Tribulus terrestris (species group 2), Kyphocarpa angustifolia (species group 13), Ocimum americanum, Achyranthes aspera (species group 19), Melhania forbesii (species group 22), Tragus berteronianus and Justicia flava (species group 28). Important grass species include Enteropogon monostachyus (species group 1), Chloris virgata (species group 19) and Tragus berteronianus (species group 28).

Species diversity in the Adenium multiflorum-Acaciagrandicornuta Sodic Bushveld is average for the Nkhuhlu exclosure site (Figure 3a) but species richness is below average, although 
TABLE 3

Richness, diversity and evenness for plant communities of the Nkhuhlu exclosure

\begin{tabular}{lcccccc}
\hline & \multicolumn{7}{c}{ Plant communities } & Nkhuhlu \\
\hline & 1 & 2 & 3 & 4 & 5 & - \\
Species Richness & 138 & 260 & 262 & 38 & 143 & 450 \\
a-Diversity (Spp/400m2) & 34 & 43 & 46 & 12 & 46 & 38 \\
Diversity & 4.029 & 4.374 & 4.626 & 2.709 & 4.133 & 5.050 \\
Evenness & 0.818 & 0.787 & 0.830 & 0.745 & 0.833 & 6.109 \\
\hline
\end{tabular}

TABLE 4

Ten most dominant plant families recorded for the five major plant communities of the Nkhuhlu exclosures site

\begin{tabular}{lrrrrrr}
\hline & \multicolumn{7}{c}{ PLANT COMMUNITIES } \\
\cline { 2 - 7 } Family & $\mathbf{1}$ & $\mathbf{2}$ & $\mathbf{3}$ & $\mathbf{4}$ & $\mathbf{5}$ & Total \\
\hline Poaceae & 17 & 44 & 19 & 15 & 25 & 66 \\
Fabaceae & 18 & 40 & 22 & 1 & 14 & 58 \\
Asteraceae & 3 & 8 & 9 & 3 & 12 & 22 \\
Malvaceae & 9 & 14 & 8 & 2 & 7 & 21 \\
Acanthaceae & 10 & 14 & 8 & 1 & 2 & 20 \\
Rubiaceae & 3 & 5 & 10 & 3 & 4 & 17 \\
Euphorbiaceae & 4 & 5 & 6 & 1 & 4 & 16 \\
Cucurbitaceae & 1 & 7 & 7 & 0 & 5 & 13 \\
Cyperaceae & 2 & 4 & 2 & 3 & 6 & 12 \\
Lamiaceae & 1 & 9 & 4 & 0 & 2 & 11 \\
\hline Number of species & 68 & 150 & 95 & 29 & 81 & 266 \\
Percentage of total & 26 & 56 & 36 & 11 & 30 & 59 \\
\hline
\end{tabular}

it hosts the highest richness of succulent plants (total of nine species) and dwarf shrubs (total of nine species) (Table 5).

\subsection{Evolvulus alsinoides-Dichrostachys cinerea Sodic Patches}

This sub-community occurs as scattered patches, predominantly within the full exclosure. The most representative patch of this sub-community occurs on the southern side of the Xiphandlukile Stream, where it is wedged between the stream and its tributary (Figure 1). Underlying soils are mainly from Montagu and Swartland forms. It is structurally characterised by a low, open shrubveld surrounded by savanna and woodland.

The Evolvulus alsinoides-Dichrostachys cinerea Sodic Patches are characterised by species group 3 (Table 1) and include Acacia nilotica, A. senegal and Rhus gueinzii in the woody layer and Evolvulus alsinoides, Asparagus setaceus, Aerva leucura and Pterodiscus speciosus in the forb layer. Dominant woody species in this sub-community include Euclea divinorum and Dichrostachys cinerea (species group 22). Prominent forbs are Blepharis integrifolia, Portulaca kermesina (species group 1), and Ocimum americanum (species group 19). Grass species that are conspicuously present include Urochloa mosambicensis, Aristida congesta (species group 13), Chloris virgata (species group 19) and Panicum maximum (species group 28).

Species richness and diversity is below average for the Nkhuhlu exclosure site (Figure 3).

\section{Enneapogon scoparius-Combretum apiculatum Dry Mixed Savanna}

This Dry Mixed Savanna belongs to the Pogonarthrio squarrosaeCombretum apiculati alliance on mesic sand (Coetzee 1983). More specifically it is classified under the 'Brushveld and treeveld with Acacia nigrescens, Eragrostis superba, Euphorbia neopolycnemoides, Hibiscus micranthus and Oropetium capense on granitic and sandstone-derived soils of the Glenrosa and Mispah forms (community 5.4 in Coetzee (1983)). According to the description of the 'Tropical Arid Granitic Lowveld of the Sabie River
Valley' by Coetzee (1983), this community comprises elements of the 'Crests and middleslopes with poorly developed soils' (landscape 1.1), the 'Crests and middleslopes with moderately well-developed soils' (landscape 1.2), as well as 'Well-drained, sandy, lower slopes'.

This community covers approximately $43 \%$ of the Nkhuhlu exclosure site and is found in all areas (including the $400 \mathrm{~m}$ buffer zone). It covers the crests and midslopes from north to south, across exclosure fence lines and the tourist road. The largest part of this community is associated with shallow, gravelly loamy sand to sandy loam topsoil directly overlying weathering rock (Glenrosa), whereas Clovelly and Mispah soil forms are also present (Paterson \& Steenekamp 2003) (Figure 4).

Structurally, the Enneapogon scoparius-Combretum apiculatum Dry Mixed Savanna is classified as a moderately closed savanna woodland and is floristically characterised by species group 4 (Table 1). The woody layer is dominated by Acacia exuvialis, Acacia nigrescens, Combretum apiculatum (species group 16, Table 1) and Dichrostachys cinerea (species group 22). Forbs such as Acalypha indica, Corbichonia decumbens, Indigofera nebrowniana (species group 4), Heliotropium steudneri, Kyphocarpa angustifolia (species group 13), Hibiscus micranthus and Waltheria indica (species group 16) are conspicuously present in this community. Important grasses include Enneapogon scoparius (species group 4), Aristida canescens, Trichoneura grandiglumis (species group 13), Digitaria eriantha (species group 16), Panicum coloratum (species group 19) and Panicum maximum (species group 28)

Species richness and diversity is high (260 and 4.374 respectively), but due to the high abundance values and dominance of species, such as Dichrostachys cinerea, Acacia exuvialis, A. nigrescens and Combretum apiculatum (Table 1), the evenness is low (Table 3 ). Half of the species constituting the Enneapogon scopariusCombretum apiculatum Dry Mixed Savanna are members of the Fabaceae and Poaceae (Table 4).

The Enneapogon scoparius-Combretum apiculatum Dry Mixed Savanna comprises three sub-communities that are not easily recognisable in the field since they form a complex pattern of interchange along the crests and midslopes of the Nkhuhlu exclosure site. This complexity is created by the gradient from bottomland to upland that runs perpendicular to the Sabie River, but also parallel to the river where it forms a gradient from midslope to crest to midslope between the two seasonal streams. Table 2 summarises the differentiation between these sub-communities based on the vegetation structure, species abundance and characteristic environmental factors.

\subsection{Melinis repens-Combretum zeyheri Crest Bushveld}

This sub-community is typically associated with crests within the Nkhuhlu exclosure site but also extends towards the bottomlands where it intersects the midslope and bottomland types. It extends over all exclosure fence lines and into the buffer zone, but is most representative on the crest alongside the tourist gravel road. The dominant soil form underlying this sub-community is Glenrosa, although a part of this community occurs on moderately deep, gravelly loamy sand to sandy loam of the Clovelly soil form (Paterson \& Steenekamp 2003) (Figure 4). It is structurally classified as a moderately closed savanna dominated by species from the Combretaceae, of which Combretum zeyheri is the diagnostic tree.

Species from species group 5 (Table 1) characterise the floristic composition of this sub-community and include Combretum zeyheri and Terminalia sericea in the tree layer, Commelina eckloniana, Clerodendrum ternatum, Indigofera fillipes and Aptosimum lineare in the forb, and Melinis repens in the 
TABLE 5

Plant species richness of different growth forms in each of the plant sub-communities of the Nkhuhlu exclosures site.

\begin{tabular}{|c|c|c|c|c|c|c|c|c|c|c|c|c|}
\hline & 1.1 & 1.2 & 2.1 & 2.2 & 2.3 & 3.1 & 3.2 & 3.3 & 4 & 5.1 & 5.2 & Total \\
\hline Annual & 19 & 11 & 33 & 13 & 22 & 16 & 9 & 23 & 10 & 25 & 28 & 71 \\
\hline Climber & $11(3)$ & $5(1)$ & 16 & $11(3)$ & $13(1)$ & $21(1)$ & $28(1)$ & 19 & 1 & 13 & 17 & $58(5)$ \\
\hline Geophyte & 1 & 1 & 3 & 1 & 0 & 2 & 2 & 1 & 1 & 1 & 1 & 6 \\
\hline Graminoid & $16[3]$ & 14 [3] & 31 [6] & $27[3]$ & $29[4]$ & $18[3]$ & 7 [2] & 28 [3] & 15 [2] & $16[4]$ & $16[6]$ & 66 [13] \\
\hline Forb & $28(3)$ & $17(1)$ & 54 & 19 & $34(1)$ & $21(1)$ & $18(1)$ & $35(1)$ & 8 & 19 & 22 & $100(6)$ \\
\hline Dwarf shrub & $9(3)$ & 3 & 8 & 5 & 7 & 3 & $7(1)$ & 7 (1) & 2 & 3 & 3 & $21(3)$ \\
\hline Shrub & 19 & 11 & 27 & 18 & 29 & 29 & 30 & 20 & 1 & 9 & 12 & 65 \\
\hline Tree & 16 & 13 & 22 & 14 & 24 & 29 & 28 & 24 & 0 & 5 & 6 & 63 \\
\hline
\end{tabular}

$[\mathrm{x}]$, annual grasses; $(\mathrm{x})$, succulent plants

grass layer. Other conspicuous woody species include Acacia exuvialis, Combretum apiculatum (species group 16), Grewia bicolor (species group 19) and Dichrostachys cinerea (species group 22). Although it was not frequently recorded, Balanites maughamii (species group 29) is another conspicuous tree. Prominent forbs are Kohautia cynanchica (species group 7), Agathesanthemum bojeri, Cyperus rupestris (species group 9), Heliotropium steudneri, Kyphocarpa angustifolia (species group 13), Ceratotheca triloba, Hibiscus micranthus, Waltheria indica (species group 16), and Abutilon angulatum (species group 22). In the grass layer Pogonarthria squarrosa, Schmidtia pappophoroides (species group 9), Digitaria eriantha (species group 16), Panicum maximum and Tragus berteronianus (species group 28) are most common.

The rocky outcrop in the centre of the partial exclosure is slightly different from typical crest Combretum veld since it contains strong elements from its surroundings (e.g. Acacia exuvialis and Acacia nigrescens) and is typically associated with marula (Sclerocarya birrea) trees. In general Sclerocarya birrea (species group 29) is associated with this sub-community, although its distribution range is too wide to be classified as diagnostic.

This sub-community has the highest number of annuals, geophytes, graminoids and forbs (Table 5), which explains its high species richness (194 taxa), the highest for the Nkhuhlu exclosure site (Figure 3b). Mean species per sampling plot is 56 , also the highest for the study area (Table 3). Plant species diversity of the Crest Bushveld was calculated at 4.050, the highest of the three sub-communities and also the highest in the study area (Figure 3a).

Two variants within the Melinis repens-Combretum zeyheri Crest Bushveld sub-community were identified and are discussed.

\subsubsection{Xerophyta retinervis variant}

This small patch of moderately open savanna is restricted to relatively rocky uplands (Table 2) on shallow soils from the Glenrosa soil form. It is most representative in the southeastern corner of the full exclosure, on the crest south of the Xiphandlukile Stream, and stretching east into the buffer zone (Figure 1). Species group 6 (Table 1) characterises this variant. The herbaceous layer, dominated by Xerophyta retinervis and Hemizygia bracteosa, is distinctly different from its surrounding counterparts. Other important diagnostic species include Bolusanthus speciosus in the tree layer and Tephrosia multijuga, Panicum natalense, Indigofera brachystachya and Cleome angustifolia in the herbaceous layer.

\subsubsection{Acacia exuvialis typical variant}

The Acacia exuvialis variant makes up the majority of the Crest Bushveld sub-community and is structurally classified as a moderately closed savanna overlying soils from the Clovelly and Glenrosa soil forms (Paterson \& Steenekamp 2003). It is found throughout the study area, excluding the sacrificial zone (Figure 1).
Species group 7 (Table 1) floristically characterises the variant, which includes the shrub Monanthotaxis caffra in the woody layer. Diagnostic forb species are Chamaecrista mimosoides, Cyperus obtusiflorus, Hermannia glanduligera, Kohautia cynanchica, Mariscus sumatrensis and Sida cordifolia. Trees such as Acacia exuvialis and Combretum apiculatum (species group 16) dominate the woody layer, with other prominent woody species being Lannea schweinfurthii (species group 9), Acacia nigrescens (species group 16), Commiphora africana, Grewia bicolor (species group 19), Dichrostachys cinerea, Grewia flavescens and Philenoptera violacea (species group 22). In the forb layer Agathesanthemum bojeri (species group 9), Heliotropium steudneri, Kyphocarpa angustifolia (species group 13), Ceratotheca triloba, Hibiscus micranthus and Waltheria indica (species group 19) are the most conspicuous. Important grasses include Eragrostis chloromelas (species group 9), Aristida congesta (species group 13), Digitaria eriantha (species group 16), Panicum coloratum (species group 19), Tragus berteronianus and Panicum maximum (species group 28).

\subsection{Urochloa mosambicensis-Cissus cornifolia Shrubby Bushveld}

This Shrubby Bushveld sub-community forms an ecotone or transition zone between the Melinis repens-Combretum zeyheri Crest Bushveld (2.1) and the Themeda triandra-Acacia nigrescens Tall Bushveld (2.3) and therefore shows strong floristic affinities towards these sub-communities. No distinct habitat type characterises this sub-community, although it is in general associated with crests and midslopes on shallow, gravelly loamy sand to sandy loam of the Glenrosa and Mispah soil forms (Paterson and Steenekamp 2003).

This moderately closed shrubland is characterised by species group 8 (Table 1) of which the succulent Cissus cornifolia shrub and short grass Perotis patens are the most conspicuous. It has strong floristic affinities to the Crest Bushveld (2.1) (species group 9, Table 1) of which the False Marula tree, Lannea schweinfurthii, and the forb Agathisanthemum bojeri provide a strong floristic link. Four of the diagnostic species are climbers (species group 9, Table 1). Dominant woody species include Acacia exuvialis, A. nigrescens, Combretum apiculatum (species group 16) and Dichrostachys cinerea (species group 22), whereas Pogonarthria squarrosa (species group 9), Trichoneura grandiglumis, Urochloa mosambicensis (species group 13), Panicum coloratum (species group 19) and Panicum maximum (species group 28) dominate the grass layer. Dense stands of Dichrostachys cinerea in some areas could lead to encroachment within this subcommunity.

The Urochloa mosambicensis-Cissus cornifolia Shrubby Bushveld is a typical representative of the surrounding savanna vegetation dominated by woody shrubs and graminoids (Table 5). Species diversity and richness is below average (Figure 3 ).

\subsection{Themeda triandra-Acacia nigrescens Tall Bushveld}

This sub-community is associated with the midslopes and bottomlands of the Nkhuhlu exclosure site, extending over all 
exclosure types, including the buffer zone. Soils underlying this sub-community are mainly from the Glenrosa and Mispah soil forms and are generally shallow and vary between gravelly sandy loam/loamy sand and sandy clay loam topsoil overlying hard rock (Paterson and Steenekamp 2003). Structurally this sub-community is classified as a moderately closed savanna that is typically associated with the dominance of scattered tall trees such as Acacia nigrescens.

Species group 10 (Table 1) contains the diagnostic species for this sub-community and includes trees such as Acacia karroo, whereas the forb Leucas glabrata and graminoids Aristida canescens, Bothriochloa radicans, Enneapogon cenchroides and Eragrostis trichophora are typically found in the field layer. Apart from the diagnostic species listed above, Acacia exuvialis, Combretum apiculatum (species group 16), Combretum hereroense, Dichrostachys cinerea and Euclea divinorum (species group 22) dominate the woody layer. Hibiscus micranthus (species group 16) and Abutilon angulatum (species group 22) dominate the forb layer. Important grasses include Themeda triandra (species group 12) and Panicum maximum (species group 28).

This sub-community has a high species richness (calculated at 158) (Figure 3b) but a below average diversity (3.504) for the Nkhuhlu study area (Figure 3). It harbours the second highest richness of graminoid, forb and shrub richness (Table 5).

Two variants within the Themeda triandra-Acacia nigrescens Tall Bushveld sub-community were identified and are subsequently discussed.

\subsubsection{Ptaeroxylon obliquum variant}

The Themeda triandra-Acacia nigrescens Tall Bushveld is mostly associated with moist bottomlands, although this variant is associated with drier midslopes on shallow, gravelly soils of the Glenrosa soil form (Paterson and Steenekamp 2003). Its distribution is restricted to the most eastern parts of the buffer zone at higher altitude than the typical variant (2.3.2).

This moderately open savanna is characterised by species group 11 (Table 1) and includes woody species such as Croton gratissimus, Euclearacemosa, Ptaeroxylonobliquum and Zanthoxylum humile, whereas Vernonia poskeana and Crossandra mucronata are common in the forb layer, and Coccinia rehmannii a prominent climber. Although diagnostic for the sub-community, the grass Themeda triandra is not prominent in this variant. Acacia nigrescens and Dichrostachys cinerea are prominent in the woody layer.

\subsubsection{Themeda triandra typical variant}

This variant represents the largest area of the Themeda triandraAcacia nigrescens Tall Bushveld sub-community. It is distributed throughout the Nkhuhlu exclosure site where it occurs at the lowest altitude of all the Combretum veld communities. It is characterised by species group 12 (Table 1), of which the herbaceous taxa Dyschoriste rogersii, Pupalia lappacea and Themeda triandra are the most prominent. Species of high abundances include Acacia exuvialis, Acacia nigrescens, Hibiscus micranthus (species group 16), Dichrostachys cinerea (species group 22) and Panicum maximum (species group 28).

\section{Jasminum fluminense-Spirostachys africana Riverine Forest}

This Riverine Forest community contains elements of the Phragmites mauritianus-Ficus sycomorus Wet Riparian Forest (community 1.2 in Bredenkamp and Van Rooyen (1991)), although there is also a relationship between this community and the Acacia robusta-Lonchocarpus capassa (= Philenoptera violacea) Riparian Woodland (community 2.1 in Bredenkamp and Van Rooyen (1991)). According to the description of the 'Tropical Arid Granitic Lowveld of the Sabie River Valley' by
Coetzee (1983), this community is furthermore floristically related to the 'Riparian bush and thicket and reed stands of seasonal river beds' (landscape 1.5 in Coetzee (1983)).

This community covers approximately $21 \%$ of the total Nkhuhlu exclosure site. It stretches alongside the Sabie River bank from north to south, as well as the riparian zone along its tributaries, such as the Xiphandlukile Stream. It also crosses over exclosure fence lines, and is the only community that occurs in all five management zones. Unlike the Dry Sodic Savanna, little structural difference could be observed between exclosure types. The largest part of this community is associated with deep, greyish-brown sand to sandy loam topsoil on brown to reddish-brown sandy-loam subsoil (Oakleaf soil form) (Paterson and Steenekamp 2003) (Figure 4).

The Jasminum fluminense-Spirostachys africana Riverine Forest is structurally classified as moderately closed woodland. True to its structural nature, it harbours the highest numbers of tree, shrub and liana taxa in the study area. Species group 4 (Table 1) floristically characterises this community, of which Spirostachys africana is the most prominent, and Dalbergia melanoxylon, Grewia hexamita and Ziziphus mucronata are present in lower abundance. Other prominent species in the woody layer are Combretum microphyllum, Diospyros mespiliformis, Euclea natalensis (species group 14), Grewia flavescens and Philenoptera violacea (species group 22). Panicum maximum (species group 28) dominates the grass layer.

This riverine forest represents the plant community in the study area with the highest species richness with a total species count of 262 and mean $\alpha$-diversity of 46 (Table 3). It also hosts the highest diversity value (4.626) at community level (Table 3). It is dominated by taxa of the Fabaceae and Poaceae, although taxa of the Rubiaceae are also well represented (Table 5).

The Jasminum fluminense-Spirostachys africana Riverine Forest is sub-divided into three sub-communities that represent smallscale differences in habitat and floristic composition.

\subsection{Tricalysia lanceolata-Dalbergia melanoxylon Streambank Woodland}

The Tricalysia lanceolata-Dalbergia melanoxylon Streambank Woodland is restricted to the woodland zones along the upper reaches of the seasonal Xiphandlukile Stream and its two tributaries, and the two smaller streams that drain the northern area in the partial exclosure and buffer zone (Figure 1). The dominant soil form underlying this sub-community is Oakleaf, although the higher lying areas are underlain by shallow soils of Mispah and Glenrosa soil forms (Paterson and Steenekamp 2003) (Figure 4). It is structurally classified as moderately closed woodland dominated by tall Tamboti (Spirostachys africana) trees.

The lower sections of this sub-community, i.e. towards the confluence of the tributaries into the Sabie River, are not as typical and broad as further upstream. Towards the Sabie River, savanna elements of Tall Bushveld (2.3) and Dry Sodic Savanna (1) enter the streambank vegetation, resulting in a sparser, savanna-like structure on the banks and narrow woodland along the stream edges. To the south the subcommunity is better developed and influenced by two factors. Firstly, the big boulder and its associated outcrops inside the full exclosure (one of few landmarks) serve as a moist microhabitat for riverine elements to colonise and therefore a strong floristic link exists with the sub-community through woody species such as Combretum imberbe, Lannea schweinfurthii, Manilkara mochisia and Ochna natalitia. Secondly, the Xiphandlukile Stream, though seasonal, flows steadily during the rainy season, which results in sufficient groundwater for woodland development. 
Species from species group 15 (Table 1) characterise the floristic composition of this sub-community and include Albizia forbesii, Berchemia discolor, Combretum mossambicense and Tricalysia lanceolata in the woody layer. Other diagnostic species are climbers, such as Adenia digitata and Dioscoria corinifolia. Dominants in the tree layer include Spirostachys africana (species group 14), Acacia nigrescens (species group 16) and Combretum hereroense (species group 22), whereas Hibiscus micranthus (species group 16), Abutilon sonneratianum, Abrus precatorius (species group 18) and Sida rhombifolia (species group 26) are prominent in the forb layer.

The number of species recorded per sampling plot is 45 and the species richness is 139 , which is above the average for the Nkhuhlu exclosure site (Figure $3 b$ ). This sub-community contains the most tree species (29) and the second highest number of liana species (Table 5). Species diversity is above average (4.044), although it scored lowest of all sub-communities in the Jasminum fluminense-Spirostachys africana Riverine Forest (Figure 3a).

\subsection{Manilkara mochisia-Diospyros mespiliformis Riverbank Woodland}

The Manilkara mochisia-Diospyros mespiliformis Riverbank Woodland is strongly associated with the Phragmites mauritianus-Ficus sycomorus Wet Riparian Forest (community 1.2 in Bredenkamp and Van Rooyen (1991)). It covers the moist, evergreen riparian zone along the Sabie River on deep soils from the Oakleaf soil form. It is well represented in the full exclosure, discontinuous and fading in the open area and absent in the partial exclosure. Several tall $(11 \mathrm{~m})$ riparian forest trees characterise this sub-community at the Nkhuhlu exclosure site. Diospyros mespiliformis is probably the most prominent big tree species. It is structurally characterised as a moderately closed to closed woodland.

Diagnostic species for this sub-community are listed under species group 17 (Table 1), of which Kigelia africana and Trichilia emetica are the major contributors to the woody layer. In the forb layer Barleria obtusa is most prominent, whereas no grass species are diagnostic for this sub-community. Panicum deustum (species group 14) and P. maximum (species group 28) are dominant in the field layer. Other prominent trees and shrubs are Euclea natalensis, Phyllanthus reticulatus (species group 14), Cordia caffra (species group 18), Combretum imberbe (species group 21), Grewia flavescens, Philenoptera violacea (species group 22) and Sclerocarya birrea (species group 29). Achyranthes aspera (species group 19) is a prominent forb, whereas the climbers Jasminum fluminense (species group 14) and Momordica balsamina (species group 21) are conspicuously present.

Species diversity is above average and was calculated at 4.092, which is the second highest value for the Nkhuhlu exclosure site (Figure 3a). It contains the most shrub and climber species, and the second highest number of tree species (Table 5).

\subsection{Lippia javanica-Gymnosporia senegalensis Riverbank Scrub}

This Riverbank Scrub is floristically related to the Acacia tortilisCombretum imberbe Riparian Woodland (community 2.1.2 in Bredenkamp and Van Rooyen 1991). Soils underlying this community are mainly from the Montagu soil form that is associated with deep sandy-loam topsoil on weakly structured calcareous subsoil (Paterson and Steenekamp 2003). This is the only sub-community that is found in all zones, including the sacrificial zone. It is significantly denser in the full exclosure than in the other zones. This sub-community is more prominent on the Sabie floodplain in the north, where there is greater impact during floods when water masses push over the banks during which riparian woodlands are washed away, leaving this short $(2 \mathrm{~m})$ shrub-dominated community (Figure 1). It is structurally classified as a moderately closed shrubland and is dominated by the spiny shrub Gymnosporia senegalensis and the grass Panicum maximum.
Diagnostic species for this sub-community are listed under species group 20 (Table 1), of which Lippia javanica is the most conspicuous. Other diagnostic species include woody species such as Flueggea virosa and Peltophorum africanum, forbs such as Acanthospermum hispidula, Hermannia tomentosa and Pavonia burchellii, and in the grass layer Cenchrus ciliaris. Other prominent species are shrubs such as Phyllanthus reticulatus (species group 14), Combretum hereroense, Euclea divinorum and Grewia flavescens (species group 22), the forb Heliotropium ovalifolium (species group 27), and Panicum deustum (species group 14), Cynodon dactylon (species group 27) and Panicum maximum (species group 28) in the grass layer. Combretum microphyllum and Jasminum fluminense (species group 14) are prominent climbers in this sub-community.

Not only is this sub-community associated with dense, straggling shrubs, but in some areas it is covered by a dense grass sward, especially of Cynodon dactylon (species group 27). These grassy areas are heavily grazed in the open area and partial exclosure. Scattered clusters of woody species are found within this sub-community. These clusters fill an important ecological role in that it serves as a microhabitat for colonisation by riparian woodland species. Many precursors of riparian woodlands were recorded from Riverbank Scrub and include Combretum hereroense, Peltophorum africanum and Cassia abbreviata.

Floristically, this sub-community is most valuable due to its high species richness and diversity - the highest for the study area (Figure 3). This sub-community is rich in all growth forms (Table 5), which partially explains why it has the highest plant species diversity in the study area.

\section{Echinochloa colona-Litogyne gariepina Seasonal Pan}

The Seasonal Pan community forms scattered patches throughout the Nkhuhlu exclosure site, although the most noticeable and best developed ones are located inside the full exclosure. All pans are located along the bottomlands of the landscape of which the majority is found in the Riverbank Woodland (3) and Dry Sodic Savanna (1). The pans in the Riverbank Woodland form part of a small, secondary channel that gets flooded when the Sabie River pushes over its banks. The pans in the Dry Sodic Savanna are typical zoogenic waterholes created by elephant, buffalo and warthog. This seasonally wet community consists of a unique composition of graminoids and dwarf shrubs. High abundance of the grass Echinochloa colona and the complete absence of tree species characterise these pans.

Diagnostic species of importance are listed under species group 23 (Table 1) and include forbs associated with moist conditions such as Litogyne gariepina and Verbena brasiliensis, and the grass Eragrostis heteromera. Other prominent species include Urochloa mosambicensis (species group 13), Panicum deustum (species group 14), Waltheria indica (species group 16), Cyperus sexangularis (species group 24), Justicia flava, Sporobolus fimbriatus (species group 28) and Chloris mossambicensis (species group 29). Species that were not recorded in a sampling plot, but were conspicuously present, include Acacia robusta, Diospyros mespiliformis $(<2 \mathrm{~m})$ and Spirostachys africana trees that surround the pans.

This community was purposefully undersampled due to its azonal status, small area, and high species turnover between pans. The floristic data presented is the cumulative richness of all four major pans. These pans are species poor with low species diversity (Table 3). Taxa of the Poaceae dominate this sub-community (Table 4) and woody species are absent (Table 5). 
5. Phragmites mauritianus-Vernonia glabra River Reedbed

This community is floristically related to the Jasminum fluminense-Phragmites mauritianus Shrubby Reed (community 1.1 in Bredenkamp and Van Rooyen (1991)) and the Ficus capreifolia-Phragmites mauritianus Riparian Thicket (community 1.4 in Bredenkamp and Van Rooyen (1991)). It furthermore fits the description of the 'Riparian bush and thicket and reed stands of seasonal river beds' (landscape 1 in Coetzee (1983)) under the 'Tropical Arid Granitic Lowveld of the Sabie River Valley' landscape (Coetzee 1983).

This River Reedbed covers approximately $11 \%$ of the total study site and is mainly restricted to the sacrificial zone. It is associated with the river bed of the Sabie River and varies from a deep, sandy reedbed to an undulating grassy river bed with exposed rock outcrops. Since it includes part of the seasonally wet river bed, its species composition can change after each rainy season. Such event-driven communities are temporal, although certain diagnostic species, such as Phragmites mauritianus remains in variable abundance.

The structural classification varies from an open river bed to a closed reedbed and has the highest cover (70\%) of herbaceous species in the study area. It is floristically characterised by species group 24 (Table 1), of which Phragmites mauritianus is most abundant. Other diagnostic species include Cyperus sexangularis, Dactyloctenium geminatum and the tree Breonadia salicina. Several alien and/or invasive forb species are prominent, such as Ageratum conyzoides, Sesbania bispinosa and Tridax procumbens. Species that are not diagnostic but conspicuously present include Cynodon dactylon, Commelina erecta, Heliotropium ovalifolium and Vernonia glabra (species group 27).

The Phragmites mauritianus-Vernonia glabra River Reedbed is floristically of the weaker communities with below average species diversity and richness (Table 3). It is dominated by taxa of the Poaceae, which is followed closely by the Asteraceae and Fabaceae (Table 4)

The Phragmites mauritianus-Vernonia glabra River Reedbed is a vegetation mosaic sub-divided into two sub-communities that represent different zones in the river bed, although at a scale too small for mapping purposes.

\subsection{Cynodon dactylon-Breonadia salicina Rocky Reedbed}

Floristically, this sub-community is related to the Securinega virosa (=Flueggea virosa)-Phragmites mauritianus Reed Scrub Thicket (community 1.1.1 in Bredenkamp and Van Rooyen (1991)). It is associated with flat to undulating, sandy alluvial plains or sand banks and terraces adjacent to the Sabie River which is characterised by herbaceous species. Although trees are scarce, they can reach $5 \mathrm{~m}$ when established between rocks.

This seasonally flooded sub-community is characterised by species in species group 25 (Table 1) of which only the climber Vigna vexillata is abundant. Other prominent species include the grasses Cynodon dactylon (species group 27) and Sporobolus fimbriatus (species group 28), the forb Heliotropium ovalifolium, and the shrub Vernonia glabra (species group 27).

This sub-community has a low species richness, although species diversity is average (Figure 3). Graminoid and forb life forms dominate this sub-community (Table 5).

\subsection{Dactyloctenium geminatum-Ficus capreifolia Sandy} Reedbed

This Sandy Reedbed is floristically related to the Ficus capreifoliaPhragmites mauritianus Riparian Thicket (community 1.4 in Bredenkamp and Van Rooyen (1991)). It is furthermore associated with the flat, deep sand banks of the Sabie River, which is seasonally flooded and characterised by the complete dominance of Phragmites mauritianus (> 50\% cover) and grass height exceeding $3.5 \mathrm{~m}$ in places.

This sub-community is characterised by species in species group 26 (Table 1), which include Ficus capreifolia as the only contributor to the woody layer. Diagnostic species in the field layer include Sida rhombifolia and Urochloa panicoides, whereas Cissampelos mucronata and Taccazea apiculata are diagnostic climbers. The exotic medicinal plant Catharanthus roseus is conspicuously present in this sub-community. Other prominent species include the grass Cynodon dactylon and the shrub Vernonia glabra (species group 27).

Species richness and diversity are low (Figure 3) and the low evenness value is explained by the dominance of the reed Phragmites mauritianus. Annual species counts are the highest in this sub-community and can be ascribed to the temporal ecology of this community since it is occasionally flooded.

\section{Conclusion}

Plant communities traverse all exclosure types at the Nkhuhlu exclosure site, except for the Echinochloa colona-Litogyne gariepina Seasonal Pan (community 4), which is absent from the partial exclosure and open control area. However, not all mapping units (sub-communities) are well represented in the different exclosure types, especially sub-communities of the Jasminum fluminense-Spirostachys africana Riverine Forest, which is only well represented in the full exclosure. Vegetationsoil relationships are well demarcated at community level, whereas small-scale environmental factors, such as flooding, rockiness and elevation are associated with sub-community differentiation. Although species richness and $\alpha$-diversity vary considerably between plant communities, the Riparian Forest community (Jasminum fluminense-Spirostachys africana Riverine Forest - community 3) hosts the highest species diversity and richness. This data can contribute towards long-term monitoring programmes along the Sabie River for designing optimal management practices along riparian ecosystems.

The granitic savanna along the Sabie River is commonly known for its undulating landscape with rather predictable vegetation patterns along the catena. In contrast, the Nkhuhlu exclosure site is a heterogeneous landscape with mosaic vegetation patterns associated with small-scale environmental variations that change along the catena. The vegetation map captured all variations up to the sub-community level. However, local small-scale heterogeneity could not be depicted due to scale and mosaic patterns. It is especially the diversity of these small-scale patches, natural or disturbed, that enhances plant diversity at the Nkhuhlu exclosure site. The Nkhuhlu exclosures along the Sabie River therefore provide immense possibilities for long-term studies of vegetation dynamics and biodiversity monitoring within a savanna riparian ecosystem.

\section{ACKNOWLEDGEMENTS}

The authors are grateful to SANParks for funding the project. Our sincere thanks to Dr Stefan Siebert (North-West University) for his assistance during field surveying and for his valuable input in this project. Mr Izak Smit is thanked for providing spatial images and shapefiles to prepare the vegetation map. The Post-flood Programme is thanked for making available digital aerial maps of the study area. GIS assistance was received from Mr Kalvin Naidoo (University of Zululand), Mr Theuns de Klerk and Ms Marie du Toit (North-West University). All field rangers are thanked for keeping a watchful eye over the field surveying team.

\section{REFERENCES}

Barbour, M.G., Burk, J.H. \& Pitts, W.D. 1987. Terrestrial plant ecology. California: Cummings. 
Bredenkamp, G.J. \& Van Rooyen, N. 1991. A survey of the riparian vegetation of the Sabie River in the Kruger National Park. Unpublished report, Ekotrust.

Coetzee, B.J. 1983. Phytosociology, vegetation structure and landscapes of the central district, Kruger National Park, South Africa. Dissertationes Botanicae, 69: 1-456.

Coetzee, B.J., Engelbrecht, A.H., Joubert, S.C.J. \& Retief, P.F. 1979. Elephant impact on Sclerocarya caffra trees in Acacia nigrescens tropical plains thornveld of the Kruger National Park. Koedoe, 22: 39-60.

Eckhardt, H.C., Van Wilgen, B.W. \& Biggs, H.C. 2000. Trends in woody vegetation cover in the Kruger National Park, South Africa, between 1940 and 1998. African Journal of Ecology, 38(2): 108-115.

Edwards, D. 1983. A broad-scale structural classification of vegetation for practical purposes. Bothalia, 14: 705-712.

Engelbrecht, A.H. 1979. Olifantinvloed op Acacia nigrescensbome in 'n gedeelte van die Punda Milia-sandveld van die Nasionale Krugerwildtuin. Koedoe, 22: 29-37.

Germishuizen, G. \& Meyer, N.L. (eds.). 2003. Plants of southern Africa: an annotated checklist. Pretoria, National Botanical Institute, Strelitzia, No. 14

Gertenbach, W.P.D. 1983. Landscapes of the Kruger National Park. Koedoe, 26: 9-121.

Hennekens, S. 1996a. MEGATAB: A visual editor for phytosociological tables [Computer program]. Version 1.0. User's guide. Ulft: Giesen \& Geurts.

Hennekens, S. 1996b. TURBOVEG: Software package for input, processing, and presentation of phytosociological data [Computer program]. User's guide. University of Lancaster: IBN-DLO.

Hill, M.O. 1979. TWINSPAN - a FORTR AN program for arranging multivariate data in an ordered two way table by classification of individuals and attributes [Computer program]. New York: Cornell University, Ithaca.

Jacobs, S. 2003. Biogeochemistry, herbivory and plant productivity in riparian ecotones and associated savanna upland ecosystems. Project proposal. Available at: http://www.sanparks. org/parks/kruger/conservation/scientific/exclosures/ [Accessed 15 January 2008]

Mucina, L., Rutherford, M.C. \& Powrie, L.W. (eds.). 2005. Vegetation map of South Africa, Lesotho and Swaziland, 1:1000 000 scale sheet maps. Pretoria: South African National Biodiversity Institute.

Mueller-Dombois, D. \& Ellenberg, H. 1974. Aims and methods of vegetation ecology. New York, Toronto: Wiley.
Paterson, D.G. \& Steenekamp, P.I. 2003. Soil survey of Nkhuhlu exclosure. ISCW Report No. GW/A/2003/39, Pretoria: ARCInstitute for Soil, Climate \& Water.

Pettit,N.E., Latterell, J.J. \& Naiman, R.J. 2006. Formation, distribution and ecological consequences of flood-related wood debris piles in a bedrock confined river in semi-arid South Africa. River Research and Applications, 22(10): 1097-1110.

Pettit, N.E. \& Naiman, R.J. 2006. Flood-deposited wood creates regeneration niches for riparian vegetation on a semi-arid South African river. Journal of Vegetation Science, 17(5): 615624.

Pettit, N.E. \& Naiman, R.J. 2007a. Fire in the riparian zone: characteristics and ecological consequences. Ecosystems, 10(5): 673-687.

Pettit, N.E. \& Naiman, R.J. 2007b. Postfire response of floodregenerating riparian vegetation in a semi-arid landscape. Ecology, 88(8): 2094-2104.

Scogings, P.F. 2005. Effects of browsing and season on defence and growth of selected woody species at the Nkhuhlu exclosure. Project proposal. Available at: http://www. sanparks.org/projects/ [Accessed 15 January 2008].

Trollope, W.S.W., Trollope, L.A., Biggs, H.C., Pienaar, D. \& Potgieter, A.L.F. 1998. Long-term changes in the woody vegetation of the Kruger National Park, with special reference to the effects of elephants and fire. Koedoe, 41(2): 103-112.

Viljoen, A.J. 1988. Long-term changes in the tree component of the vegetation in the Kruger National Park. In: MacDonald, I.A.W. \& Crawford, R.J.M. (eds.), Long-term data series relating to southern Africa's renewable natural resources. South African National Scientific Programmes Report 157. Pretoria: Foundation for Research Development, Council for Scientific and Industrial Research, pp 310-315.

Weather Bureau. 1986. Climate of South Africa. Weather Bureau Publication No. 40. Pretoria: Department of Environmental Affairs.

Wilson, B. 2003. Population dynamics and the effects of herbivory and fire on the regeneration ecology of Acacia nigrescens and Dichrostachys cinerea in the Kruger National Park, South Africa. Project proposal. Available at: http:// www.sanparks.org/parks/kruger/conservation/scientific/ exclosures/ [Accessed 15 January 2008]. 